\title{
Co - Working Space Design Preferences Factors at Surabaya
}

\section{User of Indonesia}

\author{
Drestanti Inggar Kartika $^{1}$ Purwanita Setijanti $^{2}$ Dewi Septanti $^{3}$ \\ Department of Architecture \\ Faculty of Architecture, Design, and Planning, \\ Ten November Institute of Technology \\ Surabaya, Jawa Timur \\ Indonesia
}

\begin{abstract}
Co-working space has grown rapidly throughout the world over the past 10 years. At present the co-working space is increasingly favored given the informal creative industry is increasingly developing. Creative industry players tend to like dynamics and flexibility. Co-Working Space is an ideal place for Start-Ups that are growing in Indonesia. In Surabaya, the annual growth of the rental office demand index is superior among other cities. The purpose of this study will be to identify factors that influence the preferences of user co-working space in Surabaya. The research strategy used is the correlational method, which aims to determine the correlation between the design preferences of user co-working space and variables "lifestyle/lifestyle of the creative industry. The results of this study indicate that the factors that influence the user preference design co-working space are demographic variables (age, gender), Phycycographic (motivation), income, profession, and user domicile. And the results of the study show that lifestyle users influence the design preferences of the chosen co-working space.
\end{abstract}

Key Words: Co-working space, Design preferences, Surabaya.

\section{INTRODUCTION}

The development of new businesses in urban areas has made the job hunted by the community no longer limited to formal offices. The development of Start-Ups in Indonesia has made the demand for Co-Working Space increasing (indotimes.co.id, 2017). At present the co-working space is increasingly favored given the informal creative industry is increasingly developing. These creative industry players tend to like dynamics and flexibility. The growth of Start-Ups in Indonesia has made the co-working space an ideal place for them to develop their businesses and collaborate together. Along with the advancement of the era, the essence of the office has developed. The office that was once a stand-alone building with consideration of location, but now the office is only a complete room with facilities and is charged a rental fee. Location is not the most important factor in the election to occupy the rental office, but there are several other factors considered by the company in determining decision making in occupying an office (Higgins, 2000 and Sing, 2004).

Western countries as the origin of computers and the internet gave rise to the trend of co-working space at the beginning of 2000. The concept was a workplace (coworking), where people could network and collaborate with each other, but still gave every individual the opportunity to work on their own project. Indonesia, which has long been known as a culture of mutual cooperation, soon contracted this trend from 2012. According to data compiled by the Indonesian Co-working Association and Kinetic Lab, in the last three years, the number of co-working spaces in Indonesia grew 410\%. As of July 2017, there are 123 coworking spaces in 25 locations throughout Indonesia, most in Jakarta (38 spaces) and Bandung (19 spaces), (Koran-sindo, 2017). Many developers do not understand and recognize the company and demand for office space, so this has two things: incompatibility between office tenants and available office space (Guy \& Harris, 1997). This resulted in the behavior of the 
tenants to change offices by not extending the lease or not choosing to rent the office. Tenants have the behavior to choose to move to other newer offices and offer more complete features and better quality at affordable prices.

The trend of office or workspace models in the city of Surabaya increasingly leads to the concept of Co-Working Space in line with the development of social life and technology. Urban planning observer from the Sepuluh November Institute of Technology (ITS), Johan Silas, said that the trend cycle of working and co-working space also occurs abroad, where people now tend to form communities to be able to be creative. In addition, the annual rental office demand index in Surabaya City is also superior among other cities, namely 9.21\% (Coldwell Banker Commercial Indonesia, 2016). This research is very important because in Surabaya, co-working more and more stands and continues to grow, but there is no known pattern. Thus, the existence of this research will help to identify the variables in structuring the co-working space seen from the point of design preference. From the formulation of the problem that has been elaborated, the purpose of this study is to identify the factors that influence the preferences of the user co-working space in Surabaya.

\section{LITERATURE REVIEW}

In this literature review chapter, we will discuss theories relating to this research. Theories that will be explained include the theory of offices, co-working space, consumer characteristics of co-working users and about consumer preferences.

\subsection{Co-working Space}

Co-working space is a shared workplace used by various professionals from various fields. Most of them are freelancers and include those who want to eliminate loneliness working alone in their homes and start communication with specialists from different knowledge industries. Co-working space is a place to complete work, especially work of knowledge or services originating from outside the site in other interesting activities (Foertsch, C, 2011). Co-working space is the concentration of knowledge production and knowledge distribution, and they provide an opportunity to exchange different concepts between professionals and collaboration creation that are very important for businesses, especially start-ups who do not have sufficient resources to operate without any support (Merkel, J., 2015). In conclusion, the co-working space is the perfect place for young entrepreneurs, start-ups, venture entrepreneurs, and potential public policy interventions in cities because they provide everything they need (Moriset, B, 2014)

Kwiatkowski and Buczynski (2011) develop five core values that reflect the co-working philosophy and can be considered as co-working phenomenon cradles. The following core values can be divided into:

1. Collaboration: the desire to work with others to create shared value.

2. Openness: sharing ideas, information, and people freely.

3. Community: group with a common goal and share thoughts about co-working.

4. Accessibility: co-working spaces can be accessed, both socially and economically, for each type of worker.

5. Sustainability: resources are used together, which brings economic and ecological benefits.

Co-working is often associated with self-employed workers and freelancers. However, it is clear that co-working space users are a more heterogeneous group. According to Angel Kwiatkowski and Beth Buczynski (2011), user groups of co-working spaces: self-employed, freelancers and entrepreneurs, company employees (2-10; 11-50; 50 or more) and students.

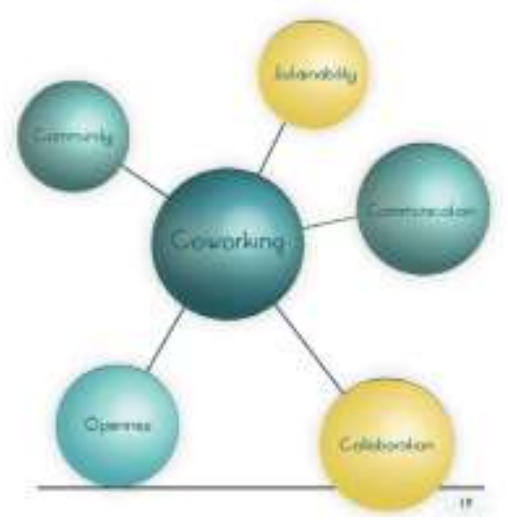

Figure 2.1: Co-working value model 
Co-working space user themselves have been identified as users who like freedom and flexibility. The users of this coworking space are dominated by creative industry players. The Indonesian Minister of Trade defines the creative industry as an industry that originates from the use of creativity, skills and individual talents to create employment welfare through the creation and utilization of the individual's creative and creative power. In this case, the creative industry is divided into 14 sub-sectors namely architecture, design, fashion, film and photography, crafts, computer services, and software, music, publishing, and printing, advertising, performing arts, research and development, antique markets, interactive games, television and radio. ("Creative Industry", 2012).

\subsection{Preferences}

Preference is defined as a tendency towards something or choice that is more favored (Alwi, 2002). Also interpreted as a right that must take precedence and priority over others. Porteus in Nursasandhari (2009) defines preference as the tendency of consumers to make decisions to choose things that they think are preferred over others. Also explained by Porteus that preferences are usually between one consumer and another consumer is not the same, so it can be used as a reference in planning something based on the desire or participation of consumers. What needs to be considered is that preference is independent of income and prices. The ability to buy goods does not determine the likes or dislikes of consumers (Besanko and Braeutigam, 2002). among others:

The psychological mindset of consumers can form preferences based on various factors that influence it (Bilson, 2004),

\section{Experience gained}

Satisfaction can be felt by consumers after making a product purchase. Consumers can also feel the compatibility in consuming the products they buy. So that consumers will continue to use these products.

\section{Hereditary beliefs}

Trust is caused by the habits of the family using a product, faithful to the product they use because of the benefits of using the product so that consumers get satisfaction and benefits from the product.

\section{Product attributes}

The budget owned by consumers is not solely affecting preferences, but there are other products attributes that influence it. According to Nugroho (2008), based on the attribute approach that what consumers pay attention to is not only physical attributes but attributes that are contained in a product.

\subsection{Interior Design}

The main purpose of interior design is to create a comfortable atmosphere for users. The atmosphere of space in interior design can arise because it is formed by the elements that compose it, namely (Ching, 1996 and Kugler, 2007):

1. Space

2. Texture

3. Lines

4. Shape

5. Lighting

6. Color

7. Respect

8. Sounds

9. Reality

10. Architectural Style

\section{METHODS}

To answer the purpose of this study, the research paradigm that is considered appropriate is the post-positivistic paradigm. Post-positivism philosophy is often also referred to as an interpretive and constructive paradigm, which views social reality as something holistic/intact, complex, dynamic, full of meaning, and the relationship of symptoms is interactive (reciprocal). Research is carried out on natural objects. Natural objects are objects that develop as they are, not manipulated by researchers and the presence of researchers does not really affect the dynamics of the object.

Based on the objectives to be achieved, the research strategy used is to use the correlational method, which aims to find out the user co-working space design preferences by looking for correlations between variables "lifestyle / lifestyle of creative industries as users of co-working space that influence the choose co-working with the variable "design co-working space suitable to be developed in Surabaya". Data collection techniques in this study were conducted by collecting primary data such as observations and questionnaires taken directly from the object of the study then correlated. 


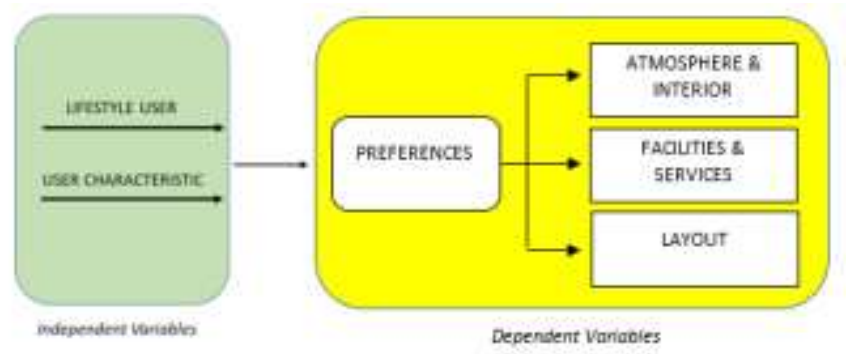

Figure 3.1: Relationship of research variables

\section{ANALYSIS}

The general description contains an explanation of the research area. While the discussion contains some data from the results of the questionnaire that has been done.

\subsection{Scope of the research area}

The scope of this research area is active co-working space in the city of Surabaya. The city of Surabaya is a bustling and crowded city number two after Jakarta. According to Johan Silas, the city of Surabaya will be the center of the world economy in the next 10-20 years (properti.kompas.com, 2015).

\subsection{Respondents Profile}

The discussion of the respondents profile was conducted not only to give an overview of the research respondents, but it was also important to conduct an analysis in the research of respondents' profiles reviewed in 5 (five) aspects, namely:

1. Demographic :
a. Respondent age
b. Respondent sex

2. Pychographic (motivation)

3. Respondent's job

4. Respondent domicile

5. Respondent's income

Respondents are co-working space users who work in the creative industry, according to the creative industry (2012), the creative industry profession is divided into 12 sub-sectors, namely architecture, design, fashion, film and photography, crafts, computer services and software, music, publishing and printing, advertising, performing arts, research, and development, antique markets, interactive games, television and radio. Research data is used to then be processed and discussed according to the research objectives.

\subsection{Demographic}

Profile of respondents based on age classification, especially those who have criteria as described in chapter 3 which are registered in Surabaya. From the survey results it was found that respondents had an age range between 20-45 years with the following comparisons:
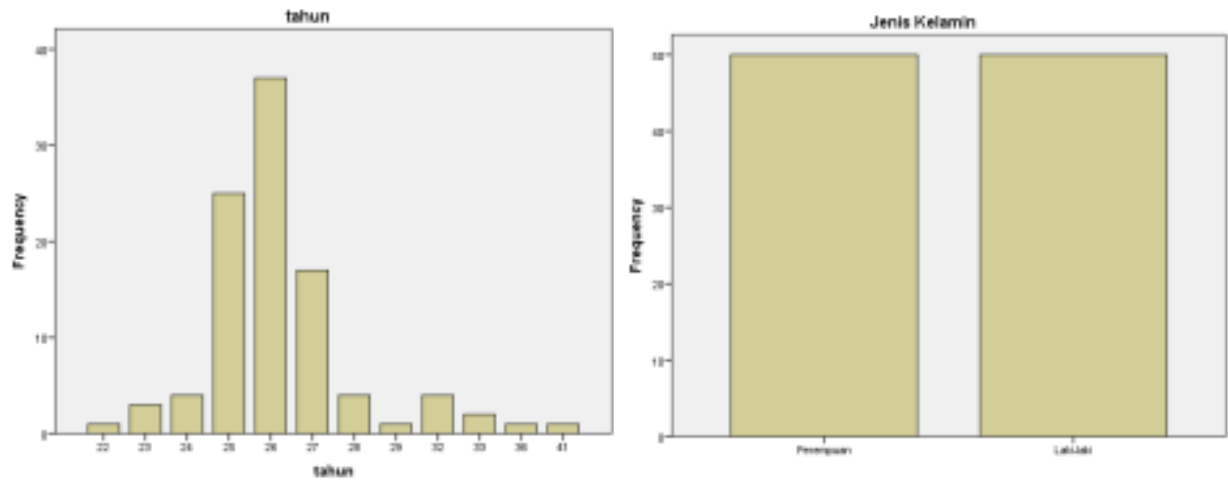

Figure 4.1: Respondents Characteristics Bar Chart by Demographic 
From the graph above, it can be seen that users or creative industries that use co-working space in Surabaya are dominated by their 20s. From this graph, it can also be seen that the creative industries in Surabaya are young people with an age range of 20 years to 35 years. The profile of respondents is based on gender. Respondents obtained in this study had an equal number, namely a number of 50 respondents with male gender and respondents with female gender of 50 people. 


\subsection{Domicile}

Respondents have the most dominant characteristics domiciled in East Surabaya with a total of 52 people. Then the next dominance of respondents domiciled in the South Surabaya area of 32 people. Respondents who are domiciled in the West Surabaya area are 11 people and those who live in the North Surabaya area are 5 people.

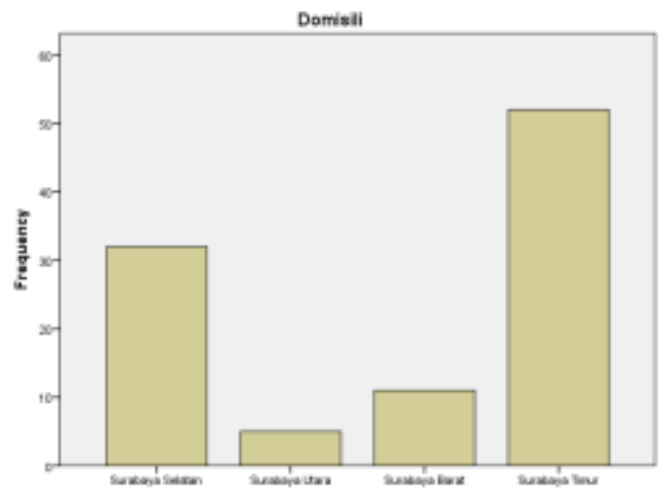

\subsection{Profession}

Figure 4.2: Respondents Characteristics Bar Chart By Domicile

According to BEKRAF (2012), the creative industry profession is divided into 12 sub-sectors, namely architecture, design, fashion, film and photography, crafts, computer and software services, music, publishing and printing, advertising, performing arts, research and development, goods market antique, interactive games, television and radio. The most respondents were 46 designers. Then the second most profession involved by respondents is the profession of architects, the position of the three highest profession respondents is in the field of research and development as well as film and photography and so on.

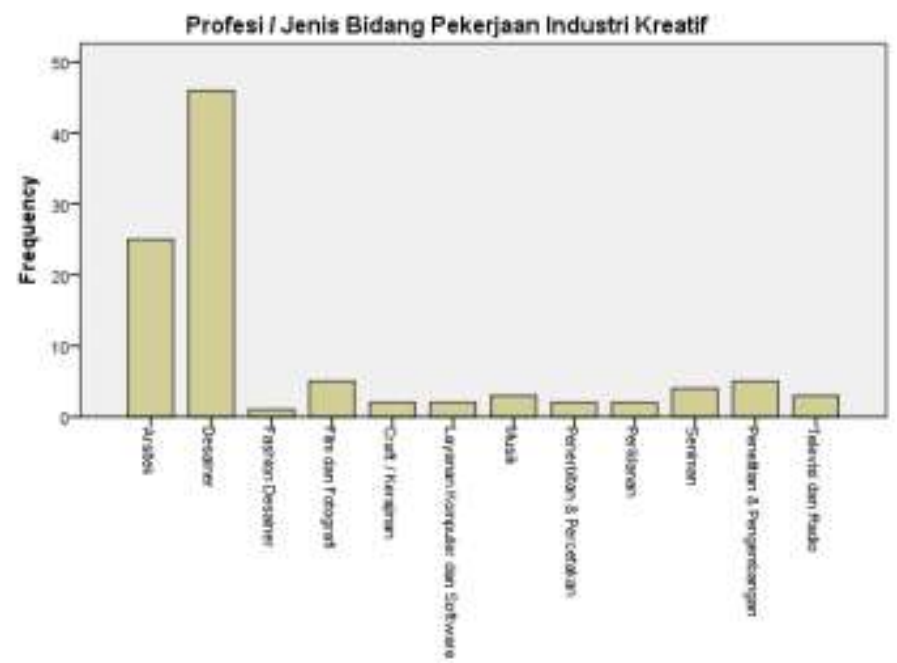

Figure 4.3: Respondents Characteristics Bar Chart by Profession

\subsection{Income}

The grouping of respondents' income ranges per month is based on the nominal UMR prevailing in Surabaya as of November 2017, which is $\operatorname{Rp} 3,583,312,003$. Here is a comparison chart:

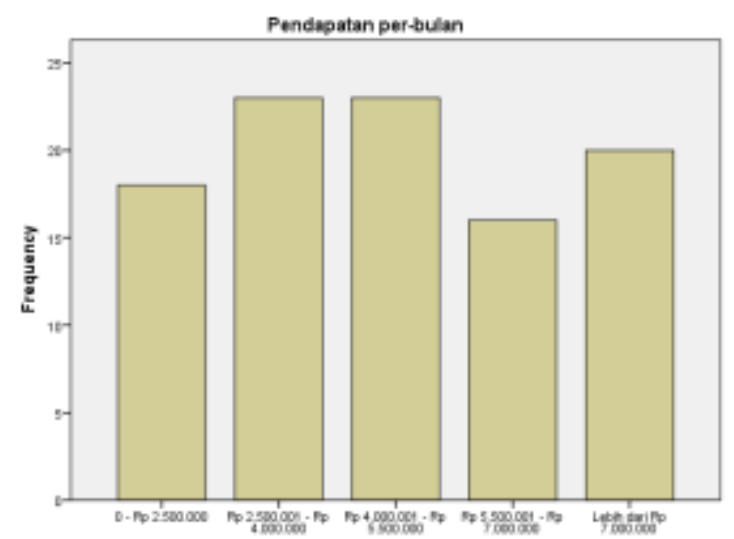

Figure 4.4: Respondents Characteristics Bar Chart by Income 
From the graph above, it can be seen that the most dominant respondents have income in the range of Rp. 2,500,001 Rp. 4,000,000 and the income range of Rp. 4,000,001 - Rp. 5,500,000 as many as 23 people each. Then income with a range of

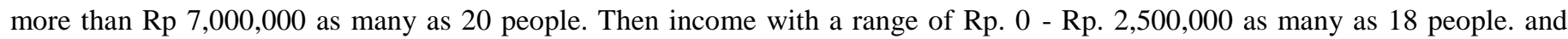
finally the income of respondents with a range of Rp.5,500,001 - Rp.7,000,000 as many as 16 people.

\subsection{Preferred Co-working Space Style Design}

Based on the observations of the researchers, the design style used as a design co-working space in Surabaya includes minimalist Scandinavian, Industrial, Colonial Modern, and Modern Contemporary. Then after identifying the design style, it is poured in a questionnaire which is then given to the respondent and then the preferred design style is chosen to find out which design style is most preferred by the user to be applied to a co-working space.

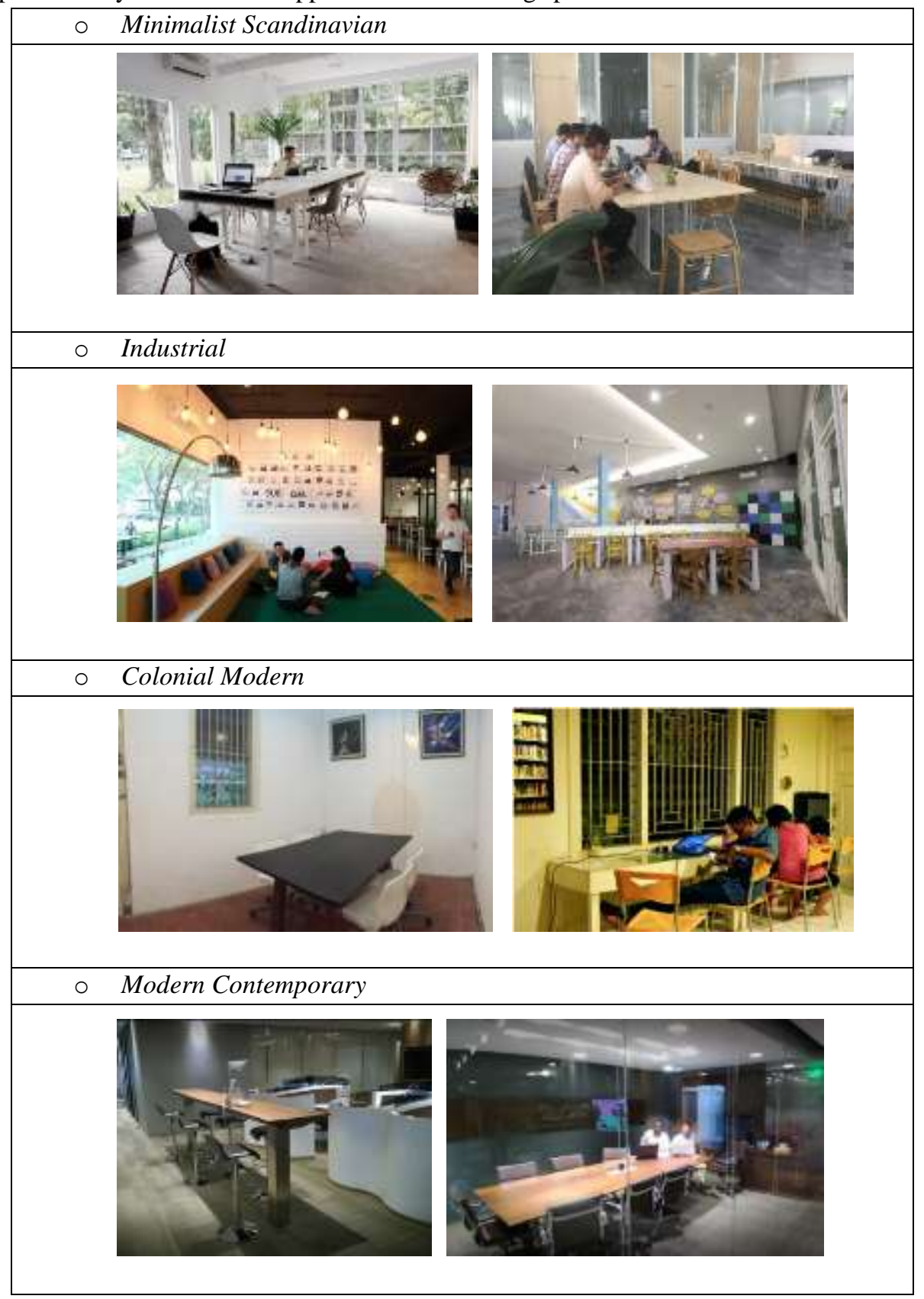

Table 4.1: Co-working Space and Applied Style Design

From the results of the questionnaire that has been distributed to 100 respondents, the results show that the design style most liked by co-users is the minimalist Scandinavian style. Then the second design style most favored by users is industrial design style. After that, the third style most favored by users is the modern colonial design style, which was chosen as many as 6 people and the least favored is the style of contemporary modern design. From these results it can also be concluded that users or creative industry users as co-working space users do not like working in a work area with a rigid and formal form such as a conventional office. 


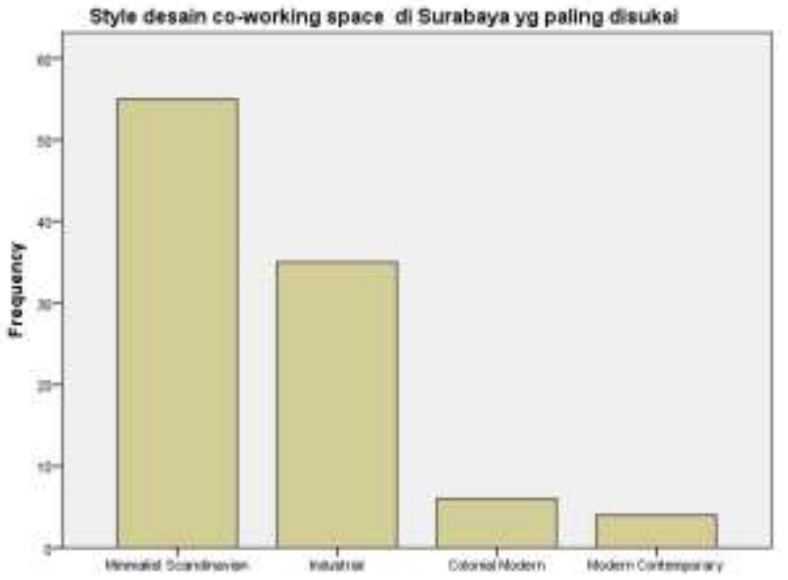

Figure 4.5: Co-working Space Design Preferences Bar Chart

\section{CONCLUSION}

From the results of this study, it can be seen that the factors that influence the preferences of co-working space users in Surabaya are demographic factors (age, sex), physiographic, profession, income, and domicile. From this research, it can also be seen that creative industry players as users of co-working space in Surabaya have the same design preferences, namely using coworking space with Scandinavian minimalist design styles and the second largest choice falling in industrial design style choices. This can be related to the lifestyle of those who like dynamics and flexibility. The results of this study can be useful for codevelopers in Surabaya to develop their business and for innovation for co-working development management.

\section{ACKNOWLEDGMENT}

Thanks to our colleagues from Institut Teknologi Sepuluh Nopember Surabaya, who provided insight and expertise that greatly assisted the research, although they may not agree with all of the interpretations/conclusions of this paper. Thanks to my lecturer for assistance with the paper, and for comments that greatly improved the manuscript.

\section{REFERENCES}

[1] Foertsch, C. Profitable Coworking Business Models. 2011. Available online: http://www.deskmag.com/en/profitablecoworking space-business-models-189.

[2] Merkel, J. Coworking in the city. Ephemera 2015, 15, 121-139.

[3] Moriset, B. Building new places of the creative economy. The rise of coworking spaces. In Proceedings of the 2nd Geography of Innovation International Conference, Utrecht, The Netherlands, 25 January 2014

[4] J.G.C. (Jasper) van de Koevering. The preferred characteristics of coworking spaces. 2017. Eindhoven University of Technology

[5] Angel Kwiatkowski and Beth Buczynski. Coworking: Building Community as a Space Catalyst. 2011.

[6] Leforestier, A. The Co-Working Space Concept. CINE Term Project; Indian Institute of Management (IIMAHD): Ahmedabad, India, 2009.

[7] Kojo, I.; Nenonen, S. User experience in an academic coworking place: The case of alto university's design factory. In Proceedings of the CIB Facilities Management Conference, Copenhagen, Denmark, 21-23 May 2014.

[8] Seo, J.S.; Lee, G.C.; Ock, Y.S. A study of coworking space operation strategy: Focused on operation elementsanalysis by AHP method. Asia-Pac. J. Bus. Ventur. Entrep. 2015, 40, 157-165.

[9] Ergin, Dyugu (2013). How to Create a co-working space handbook. Milan. Politecnico di Milan.

[10] Bilson, Simamora. (2004). Panduan Riset Perilaku Konsumen. Jakarta : Gramedia. 